\title{
Water Stress and Storage Environment Affect Pillowy Fruit Disorder in Cucumber
}

\author{
Ronald S. Thomas and Jack E. Staub ${ }^{2}$ \\ Vegetable Crops Research, U.S. Department of Agriculture, Agricultural Research Service, \\ Horticulture Department, University of Wisconsin, Madison, WI 53706
}

\begin{abstract}
Additional index words. Cucumis sativus, stomatal resistance, photosynthesis, stress index, soil moisture tension, postharvest physiology, calcium

Abstract. Mean daily stomatal resistance was higher (58\%; to 384\%), photosynthesis values lower (11\% to $49 \%)$, and crop water stress index values higher $(92 \%$ to $95 \%)$ in stressed cucumber (Cucumis sativus L.) plants than in irrigated control plants in three experiments performed in 1987 and four in 1988. Pillowy fruit disorder (PFD) was more frequent $(110 \%$ to $150 \%)$ and more severe $(59 \%$ to $81 \%)$ in freshly harvested fruits from stress plots when compared to controls. No after-storage differences in PFD were detectable between water stress treatments. Mean PFD ratings of processed fruit following postharvest storage at $26.5 \mathrm{C}$ and either $60 \%$ or $75 \%$ relative humidity were significantly higher than ratings of fruit stored at either 10.5 or $15.5 \mathrm{C}$ and $85 \%$ relative humidity. The progressive development of pillowy and the observed enhancement of PFD symptoms following storage at higher storage temperatures indicated that postharvest changes can occur in fruit mesocarp tissue and that the development of PFD can be altered, to some extent, during storage. Negative correlations $(-0.18$ to -0.78$)$ between fruit quality and PFD ratings suggested that these changes can affect processed product quality. Pillowed tissue of processed fruit was significantly softer $(33 \%$ to $39 \%)$ than nonpillowed tissue.
\end{abstract}

Limited information exists on physiological effects of water stress in cucumber. Nagoaka et al. (1984) reported leaf water potentials of -5 to -6 bars when cucumber plants grown in assimilation chambers were adequately irrigated. Rates of $\mathrm{CO}_{2}$ assimilation and transpiration declined when leaf water potentials fell below -6 to -7 bars, and severe wilting of plants occurred at water potentials less than -9 bars. Cho et al. (1985), measuring cucumber leaf temperatures at various soil water potentials in a greenhouse environment, found decreases in transpiration when soil water potentials fell below $\approx 1$ bar. Drews (1979) also reported a decline in cucumber transpiration rate when soil moisture fell below $80 \%$ of field capacity. Cho et al. (1985) therefore hypothesized that reduction in soil water potential restricted water uptake, causing a decrease in leaf water potential, which, in turn, resulted in lowered transpiration rates.

In a greenhouse study, Ortega and Kretchman (1982) examined fruit growth rates of well-watered cucumber plants and those maintained in a "wilted" condition. Their results indicated that fruit growth rate was severely reduced in stressed plants. Further, large fruit (> 27 to $59 \mathrm{~mm}$ in diameter) under stress seemed to receive available water at the expense of small fruits $(<15$ to $32 \mathrm{~mm}$ in diameter).

Field research has focused on yield response to irrigation. In pickling cucumber, significant yield increases and reductions in the number of culls have been reported for plants receiving adequate water when compared to nonirrigated plants (O'Sullivan, 1980; Reynolds and Rogers, 1949; Tan et al., 1983). Characterization of stress levels imposed in these studies, however, has been limited to descriptions of soil moisture content. Moreover, other than yield, no physiological plant attributes were measured in the plants.

Received for publication 30 Oct. 1991. Accepted for publication 4 Feb. 1992. Mention of a trade name, proprietary product, or specific equipment does not constitute a guarantee or warranty by the U.S. Dept. of Agriculture and does not imply its approval to the exclusion of other products that may be suitable. The cost of publishing this paper was defrayed in part by the payment of page charges. Under postal regulations, this paper therefore must be hereby marked advertisement solely to indicate this fact.

'Former Graduate Research Assistant.

${ }^{2}$ Research Horticulturist and Associate Professor.
Recently, a fruit disorder related to Ca deficiency in processing cucumber was reported (Staub et al., 1988). The defect, which appears in the mesocarp of affected fruits, is called "pillowy." This term describes the styrofoam-like, white, porous appearance of the disorder in freshly harvested cucumbers. Following fresh-pack processing, pillowed tissue assumes a characteristic water-soaked, tan to grayish-brown discoloration that reduces product quality.

Experiments using greenhouse solution culture have shown that PFD is associated with significantly lower levels of tissue $\mathrm{Ca}$ in affected fruits when compared to normal cucumbers (Staub et al., 1988). When transpiration of plants was restricted at high relative humidity, lower fruit $\mathrm{Ca}$ levels and more pillowed fruit were produced than when fruits enlarged on plants that were grown under ambient conditions.

In view of the known effects of moisture conditions on the PFD disorder, studies were undertaken to: 1) determine if plant water stress during fruit growth contributes to the development of pillowy fruits; 2) compare indices of water stress; and 3) determine if postharvest handling procedures increase PFD injury. Therefore, comparisons were made between fruits harvested from plants subjected to water stress (stress) and fruits harvested from plants with adequate soil moisture conditions (no stress; control) for pillowy symptoms. To determine whether postharvest storage conditions affect the frequency and intensity of pillowy, fruits obtained from field plantings maintained under water stress were subjected to several combinations of temperature, relative humidity, and storage duration before processing.

\section{Materials and Methods}

Water stress. 'Calypso' plants were grown in a Plainfield loamy sand (Typic Udipsamment; mixed, mesic) at the Univ. of Wisconsin Experiment Station, Hancock. In three experiments in 1987 and four experiments in 1988, adjacent randomly assigned treatments (control and stress) $4 \mathrm{~m}$ apart were subdivided into quadrants. Each treatment consisted of three 6. 1-m-

Abbreviations: CWSI, crop water stress index; OVR, overall fruit quality rating; P, photosynthesis; PFD, pillowy fruit disorder; RH, relative humidity; SMT, soil moisture tensions; SR, stomatal resistance; VPD, vapor pressure deficit. 
long rows with end $(0.75 \mathrm{~m})$ and side $(7.6 \mathrm{~m})$ plot borders. Cucumbers were planted in rows $1.5 \mathrm{~m}$ apart and spaced $10 \mathrm{~cm}$ apart in the row for a density of 64,550 plants/ha. Standard fertilization practices, spray schedules, and cultivation by hand were used throughout.

From planting until initiation of stress, all plants received a minimum of 6 or $10 \mathrm{~mm}$ of water each day in 1987 and 1988, respectively, which was supplied daily through a zoned, drip irrigation system placed adjacent $(\approx 65 \mathrm{~mm})$ to plants in each row. If rain provided more than that amount, no irrigation was applied. Stress treatments were protected from rainfall during stress periods by motorized "rainout shelters."

To permit direct comparisons of physiological responses to water stress, stress intervals were timed to coincide with fruit enlargement before a second harvest. Synchronization of fruiting in control and stress treatments was accomplished by harvesting fruit longer than $\approx 38 \mathrm{~mm}$ at the initiation of stress. Water was withheld immediately after first harvest. Each experiment was terminated after 4 to 7 days when $30 \%$ to $40 \%$ of fruits within a treatment were $\approx 4.0 \mathrm{~cm}$ in diameter and plants were wilted.

During stress intervals, soil moisture tensions were monitored daily using tensiometers placed randomly in one row of each quadrant (four tensiometers per treatment). In 1987 and in Expt. 1 of 1988, soil moisture tensions (SMT) were monitored at a depth of $152 \mathrm{~mm}$ (Model 2100F; Soil Moisture Equipment Co., Santa Barbara, Calif). During 1988, Expts. 2-4, SMTS were recorded at a depth of $228 \mathrm{~mm}$ (Model 112; Irrometer Co., Riverside, Calif.).

Stomata! resistance (SR) and photosynthesis $(\mathrm{P})$ were recorded daily between 10:00 and 14:00 HR during stress intervals when irradiance was relatively high (1373 \pm 361 and $1510 \pm$ $347 \mu \mathrm{mol} \cdot \mathrm{m}^{-2} \cdot \mathrm{s}^{-1}$ during data collection in 1987 and 1988 , respectively). Measurements were taken on the fourth leaf from the terminal whorl of each of six randomly selected plants within a quadrant (two plants per row) using a portable photosynthesis system (LI-COR 6000; LI-COR, Lincoln, Neb.). A daily crop water stress index (CWSI) was obtained at 14:00 HR for each row within a quadrant using an infrared, remote-sensing device (Schedule; Standard Oil Engineered Materials Co., Solon, Ohio). CWSI is based on an empirically derived, linear relationship between crop and air temperature difference and vapor pressure deficit of the air (Idso, 1982; Idso et al., 1981). Daily visual ratings of plant wilting were recorded at 9:00 and 14:00 HR for each treatment. Plants showing no visual loss of leaf turgor, wilting of leaves from base to mid-vine, and wilting of leaves from base to terminal whorls were classified as no-wilt, moderate wilt, and severe wilt, respectively.

Leaves were sampled for Ca concentration just before and following a stress period in 1988 by use of inductively coupled plasma techniques (Schulte et al., 1987). The youngest, fully expanded leaves (usually the eighth node), from nine randomly chosen plants in each quadrant of control and stress treatments were combined. Soil samples were also taken at the beginning of a stress period for $\mathrm{Ca}$ analysis as a composite from 12 random locations in each treatment.

Data from control and stress treatments in each experiment were compared by regressing independent variables (SMT, SR, CWSI, and P) on time (days of stress; 4 to 7) (Steel and Torrie, 1980). Differences among treatments in each experiment were examined by comparing regression slope estimates for their equality. Before analysis of CWSI, Scheduler indices were ad- justed for low-vapor-pressure deficit conditions using a proprietary formula developed by the manufacturer.

Postharvest conditions. At harvest, fruits $\approx 40 \mathrm{~mm}$ in diameter from each treatment were randomly separated into four groups. Within $3 \mathrm{~h}$ of harvest, a group of fruits (designated as "unprocessed") from each treatment in an experiment was rated for PFD symptoms. Fruits were classified as pillowed if an opaque-white, porous tissue was observed in the mesocarp between 2 to $4 \mathrm{~mm}$ under the epidermis. Severity ratings were: slight, pillowed tissue in $1 \%$ to $20 \%$ of mesocarp tissue; moderate, $21 \%$ to $40 \%$ of fruit pillowed; extreme, $\geq 41 \%$ pillowed tissue.

In 1988, pillowed mesocarp tissue from visually similar regions of affected and unaffected fresh fruits were sampled for $\mathrm{Ca}$. Samples were dried at 70C, ashed overnight at 550C, and analyzed by standard atomic absorption spectrophotometry. Because no consistent differences in mesocarp tissue $\mathrm{Ca}$ concentrations within treatments (stress and well-watered) were detected among fruit varying in PFD severity, data in each treatment were combined for analysis. Student's $t$ tests (Johnson and Bhattacharyya, 1985) comparing the mean mesocarp Ca content of control and stress fruits were performed separately for each experiment in 1988.

The remaining three groups of fruit from each treatment in an experiment were placed for 2 to 4 days in various conditions of temperature and relative humidity $(\mathrm{RH})$ in controlled environments. In 1987, field-grown cucumber fruit were subjected to either: 1) $10.5 \mathrm{C}, 85 \% \mathrm{RH}$ [vapor pressure deficit (VPD) $0.189 \mathrm{kPa}$ ] for 4 days; 2) $15.5 \mathrm{C}, 85 \% \mathrm{RH}$ (VPD $0.257 \mathrm{kPa}$ ) for 4 days; or 3) 26.5C, 75\% RH (VPD $0.837 \mathrm{kPa}$ ) for 2 days. Postharvest storage conditions in 1988 consisted of: 1) $15.5 \mathrm{C}$, $85 \% \mathrm{RH}$ for 4 days; 2) 26.5C, $60 \% \mathrm{RH}$ (VPD $1.34 \mathrm{kPa}$ ) for 2 days; and 3) $26.5 \mathrm{C}, 75 \% \mathrm{RH}$ for 2 days. We did not keep VPD constant because we intended to simulate conditions during truck transport of pickling cucumbers. At the end of the storage period, fruits were halved, rated for PFD as described above ("processed" group), and fresh-pack processed in brine solution supplied by the Claussen Pickle Co., Woodstock, 111.

Analyses of variance of PFD ratings of fresh fruit and of fruits subjected to postharvest storage were performed separately for each experiment, and means were separated using Duncan's multiple range test at $P=0.05$.

Processed cucumbers were held at $5 \mathrm{C}$ for $\approx 3$ to 3.5 months in 1987 and $\approx 2$ to 2.5 months in 1988 and then were evaluated for presence and severity of PFD by a five-member panel of industry representatives. Symptoms of PFD were rated on a four-point scale $(1=$ no pillowy, $2=$ slight $(1 \%$ to $20 \%), 3$ $=$ moderate $(21 \%$ to $40 \%)$, and $4=$ severe pillowy $(\geq 41 \%)$. Exterior and interior color, shape, texture, and overall quality were evaluated using a five-point rating system $(5=$ excellent, $4=\operatorname{good}, 3=$ fair, $2=$ poor, and $1=$ unacceptable). Analyses of variance and mean separations of evaluations for all traits were performed separately for each experiment. Water stress treatment (field) x controlled environment (storage procedures) interactions were infrequent and inconsistent, and so data were analyzed collectively by year over experiments for each of the three storage environments. To determine the relationship between PFD and fruit quality, correlations were calculated between evaluations for fruit quality attributes and PFD ratings in each experiment.

Processed pillowed and nonpillowed tissue samples from seven to nine fruit per storage treatment were randomly selected and 
tested for softness by compression (kilograms per square centimeter) using a Universal Testing Machine (Instron Model 1130; Instron Engineering Corp., Canton, Mass.). Radially excised plugs, $1.27 \mathrm{~cm}$ in diameter in 1987 and $1.75 \mathrm{~cm}$ in diameter in 1988, were sampled from the stem end of cucumber halves. After removal of the peel, mesocarp tissue samples were trimmed to unit thickness $(0.48 \mathrm{~cm}$ in 1987 and $0.64 \mathrm{~cm}$ in 1988) 'and compressed by $75 \%$ at a crosshead speed of $0.254 \mathrm{~cm} \cdot \mathrm{min}^{-1}$. Mesocarp sample diameter and thickness were increased in 1988 to enhance the precision of compression measurements (F. Buelow, personal communication, 1987). Comparisons of mean pressure required to compress pillowed and nonpillowed samples were made using a Student $t$ test.

\section{Results}

Indices of water stress. Although wilting of plants was observed during stress periods in nonirrigated treatments in all experiments, plants recovered during the evenings and nights. Control plants exhibited no visually detectable wilt symptoms. The soil (SMT) and plant characteristics (SR, CWSI, and P) we measured furnished quantitative information regarding wilt during stress periods. Significant regression slope estimates (b values; Table 1) indicated significant differences in responses between stressed and well-watered plants during a stress episode. Inequality between treatment slope estimates (control and stress) suggested differences in plant response during stress periods as judged by each characteristic.

Mean SMT values and regression estimates (Table 1) indicated that differences in soil moisture status existed among treatments after water was withheld. With the exception of Expt. 1 in 1988, daily mean SMT of control plots was maintained at $<25.1 \mathrm{kpa}$ (detailed data not presented). Regression estimates indicated that irrigation prevented increases in SMT during stress periods. Mean SMT of stress plots increased from 5.0 to 12.7 $\mathrm{kPa} \cdot \mathrm{day}^{-1}$ (b values not presented), indicating a reduction in soil. moisture during stress. Slope inequality among treatments indicated different time-course trends in soil moisture content.
Plant responses to soil moisture reduction were measured by SR, CWSI, and P (Table 1). In all experiments, mean SR values were higher, P levels lower, and CWSI values higher in stressed plants than in controls. Mean daily SR values of control plants were $<0.82 \mathrm{~s} \cdot \mathrm{cm}^{-1}$, while values of plants under stress exceeded $1.03 \mathrm{~s} \cdot \mathrm{cm}^{-1}$ for a minimum period of 2 days (six of seven experiments; detailed data not presented). Where significant, SR responses of controls (b values) were either slightly positive $\left(0.08\right.$ and $\left.0.17 \mathrm{~s} \cdot \mathrm{cm}^{-1}\right)$ or slightly negative $(-0.01$ to $\left.-0.07 \mathrm{~s} \cdot \mathrm{cm}^{-1}\right)$ when compared to significantly positive responses in stress treatments $\left(0.16\right.$ to $\left.0.37 \mathrm{~s} \cdot \mathrm{cm}^{-1}\right)$. Significant slope equality differences between treatments (six of seven experiments) are indicative of differential SR response between well-watered and stressed plants.

While CWSI values $<2.0$ generally indicate that plants were well watered, values $>2.0$ reflect negative effects of water stress (Standard Oil Engineered Materials Co., 1987). Mean CWSI values of plants in control plots were consistently $<2.0$, while plants in stress treatments exceeded 2.0 (Table 1). Nonsignificant or significant negative slopes in six of seven control treatments suggested that plants were receiving sufficient moisture to maintain CWSI values at noncritical levels (data not presented). Values of $b$ of plants in stress treatments were significantly positive, and mean CWSI values increased by 0.74 to 2.07 units per day during stress periods (detailed data not presented). Based on treatment slope equality comparisons, increases in CWSI values were significant.

Mean $\mathrm{P}$ values reflect relative treatment differences in apparent photosynthetic activity of plants (Table 1). Control plants exhibited higher net carbon assimilation than those in stress treatments (19\% to $28 \%$ in 1987 and $16 \%$ to $48 \%$ in 1988). Significant negative $b$ values manifested by stressed plants represent decreases in $\mathrm{P}\left(0.03\right.$ to $0.08 \mathrm{mg} \mathrm{CO} / \mathrm{m}^{2}$ per second per day), while control plants exhibited no such change (detailed data not presented). Slope equality comparisons of treatments indicated that plant $\mathrm{P}$ responses were significantly different $(\mathrm{P}$ $>0.07)$ in five of seven experiments.

Table 1. Estimates of SMT, SR, CWSI, net P, and response (regression) of cucumber plants exposed to water stress.

\begin{tabular}{|c|c|c|c|c|c|c|c|c|c|c|c|c|c|c|c|c|}
\hline \multirow[b]{4}{*}{ Variable } & \multicolumn{8}{|c|}{1987} & \multicolumn{8}{|c|}{1988} \\
\hline & \multicolumn{4}{|c|}{ Mean } & \multicolumn{4}{|c|}{ Regression estimates ${ }^{z}$} & \multicolumn{4}{|c|}{ Mean } & \multicolumn{4}{|c|}{ Regression estimates } \\
\hline & \multicolumn{2}{|c|}{ At harvest } & \multicolumn{2}{|c|}{ Cumulative } & \multirow[b]{2}{*}{ b } & \multirow[b]{2}{*}{ SE } & \multirow[b]{2}{*}{$R^{2}$} & \multirow{2}{*}{$\begin{array}{l}\text { Slope } \\
\text { inequity } \\
\text { (P) }\end{array}$} & \multicolumn{2}{|c|}{ At harvest } & \multicolumn{2}{|c|}{ Cumulative } & \multirow[b]{2}{*}{$\mathrm{b}$} & \multirow[b]{2}{*}{$\mathrm{SE}$} & \multirow[b]{2}{*}{$R^{2}$} & \multirow{2}{*}{$\begin{array}{l}\text { Slope } \\
\text { inequity } \\
\text { (P) }\end{array}$} \\
\hline & $X_{y}$ & SE & $\mathrm{X}^{\mathrm{x}}$ & $\mathrm{SE}$ & & & & & $\mathrm{X}$ & SE & $\mathrm{X}$ & SE & & & & \\
\hline \multicolumn{17}{|l|}{ SMT (kPa) } \\
\hline Watered dailyw & 11.8 & 4.8 & 13.4 & 1.8 & 0.8 & 1.5 & 0.12 & & 4.6 & 4.2 & 12.2 & 1.9 & -3.7 & 1.1 & 0.08 & \\
\hline Water withheld & 80.4 & 13.1 & 67.3 & 3.1 & $10.1^{* * *}$ & 1.8 & 0.60 & 0.006 & 62.9 & 13.1 & 44.7 & 4.6 & $10.3^{* * *}$ & 1.4 & 0.71 & 0.03 \\
\hline \multicolumn{17}{|l|}{$\mathrm{SR}\left(\mathrm{s} \cdot \mathrm{cm}^{-1}\right)$} \\
\hline Watered daily & 0.46 & 0.23 & 0.54 & 0.03 & $0.03^{* *}$ & 0.03 & 0.07 & & 0.50 & 0.11 & 0.47 & 0.02 & $-0.20^{* *}$ & 0.01 & 0.21 & \\
\hline Water withheld & 0.92 & 0.31 & 1.15 & 0.07 & $0.27^{* * *}$ & 0.06 & 0.13 & 0.001 & 2.41 & 1.45 & 1.46 & 0.10 & $3.25^{* * *}$ & 0.05 & 0.28 & 0.001 \\
\hline \multicolumn{17}{|l|}{ CWSI } \\
\hline Watered daily & 0.9 & 0.2 & 1.2 & 0.2 & -0.03 & 0.24 & 0.03 & & 1.5 & 0.9 & 1.3 & 0.2 & 0.10 & 0.11 & 0.01 & \\
\hline Water withheld & 5.3 & 1.7 & 4.7 & 0.4 & $0.63^{*}$ & 0.53 & 0.06 & 0.35 & 7.8 & 2.8 & 5.0 & 0.5 & $1.31^{* * *}$ & 0.23 & 0.37 & 0.001 \\
\hline \multirow{2}{*}{\multicolumn{17}{|c|}{ Net $\mathrm{P}$ ( $\mathrm{mg} \mathrm{CO} / \mathrm{m}^{2}$ per sec per day) }} \\
\hline Watered daily & 0.55 & 0.09 & 0.60 & 0.01 & -0.03 & 0.02 & 0.07 & & & & & & & & & \\
\hline Water withheld & 0.44 & 0.04 & 0.48 & 0.01 & -0.05 & 0.01 & 0.12 & 0.36 & 0.36 & 0.14 & 0.49 & 0.02 & $-0.5^{* * *}$ & 0.01 & 0.17 & 0.025 \\
\hline
\end{tabular}

${ }^{2}$ Watered daily and water withheld compared by regressing variables over time.

${ }^{y}$ Means of three and four experiments in 1987 and 1988, respectively.

${ }^{x}$ Means of combined (five to eight) stress days over three and four experiments in 1987 and 1988, respectively.

"Water stress treatments when control equals sufficient soil moisture for growth and development, and stress equals soil moisture withheld to cause wilting during second harvest fruit enlargement.

$*$, **, ***Significant at $P=0.05,0.01$, or 0.001 , respectively. 
Soil and leaf analyses for Ca provided evidence that levels were adequate for normal growth and development. Combined mean soil Ca levels at the beginning of stress in 1988 were 1276 $\pm 124 \mathrm{~kg} \cdot \mathrm{ha}^{-1}$, and $1178 \pm 210 \mathrm{~kg} \cdot \mathrm{ha} \mathrm{f}^{-1}$ for control and stress treatments, respectively. Combined mean percent leaf $\mathrm{Ca}$ (on a dry-weight basis) was $2.66 \% \pm 0.6 \%$ for controls and $2.28 \%$ \pm 0.470 for stress treatments.

Fresh fruit evaluations. Pillowed fruit were present in control and stress treatments when unprocessed fruits were analyzed for PFD within $3 \mathrm{~h}$ of harvest. In 1987, the combined (three experiments) frequency of PFD in fruits from well-watered plants was $40 \%$, while fruit that matured in plots under water stress conditions were $100 \%$ pillowed. Similarly in 1988 , the combined (four experiments) frequency of PFD was $42 \%$ in control fruits and $87 \%$ in fruits harvested from stress plots. Significant differences $(P>, 0.05)$ in the severity of PFD between wellwatered and water-stressed plants were found in each experiment. Combined mean severity ratings for PFD in 1987 were 1.91 and 3.45 for fruit from control and stress plots, respectively. Fruits from well-watered plots exhibited a combined mean PFD rating of 1.5 in 1988, while the mean PFD severity rating of fruit matured under stress conditions was 2.4. In 1988 experiments, the mesocarp tissue of control fruits contained significantly more $\mathrm{Ca}$ than samples from fruits matured under stress (Table 2).

Postharvest experiments. Water stress and postharvest storage affected the severity of PFD in unprocessed (four of seven experiments; Table 3) and processed (six of seven experiments; Table 4) fruit. Severity of PFD in control fruit, before and after storage, was less (13\% to 20\%) than in fruit harvested from stress treatments. Two-way and nested three-way interactions were infrequent and inconsistent.

In five of the seven experiments, the severity of PFD following extended storage was higher than in fresh fruits (Table 3). Moreover, PFD severity increased with increasing storage temperature and VPD. PFD was more severe following storage at $26.5 \mathrm{C}$ than either 10.5 or $15.5 \mathrm{C}$ in 1987. In 1988 , storage of fruit at $26.5 \mathrm{C}$ and either $60 \%$ or $75 \%$ relative humidity resulted in greater severity of PFD than storage at $15.5 \mathrm{C}$.

Differences in the frequency of PFD between control and stress treatments were not detected immediately after postharvest storage. When data from controlled environments in 1987 were considered collectively, the frequency of PFD was $100 \%$ in both control and stress treatments. The frequency of PFD following storage in 1988 was $95 \%$ and $94 \%$ for control and stress fruits, respectively.

No significant interactions were detected for water stress treatment $\mathrm{x}$ judge or for treatment $\mathbf{x}$ storage environment interactions, and experimental variation was relatively low $(\mathrm{CV}=$ $14.3 \%$ and $27.7 \%$ ). As observed in fruit before processing, water stress treatments had no significant effect on PFD. Since

Table 2. Mesocarp tissue Ca (percent dry weight) for cucumber fruits produced in four water stress experiments, 1988.

\begin{tabular}{|c|c|c|c|c|c|c|c|}
\hline \multirow[b]{3}{*}{ Experiment } & \multicolumn{6}{|c|}{ Water stress } & \multirow{3}{*}{$\begin{array}{c}t \text { Test } \\
P \text { value }\end{array}$} \\
\hline & \multicolumn{3}{|c|}{ Absent } & \multicolumn{3}{|c|}{ Present } & \\
\hline & $\mathrm{n}$ & $\overline{\mathrm{X}}_{\mathrm{c}}$ & SD & $\mathrm{n}$ & $\overline{\mathrm{X}}_{\mathrm{s}}$ & SD & \\
\hline 1 & 21 & 0.233 & 0.073 & 19 & 0.189 & 0.084 & 0.20 \\
\hline 2 & 17 & 0.285 & 0.080 & 12 & 0.125 & 0.022 & 0.01 \\
\hline 3 & 12 & 0.310 & 0.050 & 13 & 0.225 & 0.070 & 0.01 \\
\hline 4 & 12 & 0.335 & 0.098 & 7 & 0.204 & 0.060 & 0.01 \\
\hline
\end{tabular}

${ }^{2}$ Hypothesis test $=\mathrm{H}_{\mathrm{o}}: \overline{\mathrm{X}}_{\text {control }}-\overline{\mathrm{X}}_{\text {stress }}=0$. overall fruit quality ratings (OVR), with the exception of exterior color, were highly correlated $(0.53$ to $0.88 ; P=0.01)$ with the other quality attributes evaluated, only data on OVR were presented.

Where differences occurred, judges were consistent in assigning lower OVR ratings to processed fruits rated more severely for PFD. Consistently significant $(P=0.01)$, negative correlations $(-0.18$ to -0.78$)$ between fruit quality attributes and PFD ratings confirmed the association between the presence and severity of PFD and lower fruit quality. Water stress treatment affected OVR and PFD severity in four of seven and three of seven experiments, respectively (Table 4). Likewise, significant postharvest storage effects on OVR and PFD were identified in six of seven and seven of seven experiments, respectively.

Increasing severity of PFD symptoms and correspondingly lower overall fruit quality in processed fruits were associated with increased postharvest storage temperature and VPD (Table 4). With the exception of Expt. 1 in 1988, mean PFD ratings of processed fruits following postharvest storage at $26.5 \mathrm{C}$ and either $60 \%$ or $7590 \mathrm{RH}$ were significantly higher than those of fruit stored at either 10.5 or $15.5 \mathrm{C}$ and $85 \% \mathrm{RH}$. Conversely, judges' mean OVR ratings for fruits held at $26.5 \mathrm{C}$ were significantly lower than those for fruit stored at lower temperatures. Regardless of storage condition, pillowed tissue was softer (33\% to 39\%) than nonpillowed tissue (Table 5).

\section{Discussion}

Although PFD was present in both treatments at harvest, differences in the frequency and severity of pillowy in fresh fruits suggested that water stress was a factor that contributed to the development of PFD. In both years, PFD was $110 \%$ to $150 \%$ more frequent and $59 \%$ to $81 \%$ more severe in freshly harvested fruits from stress plots than in those from the controls. These results paralleled those of greenhouse experiments where PFD was correlated with reduced transpiration (Staub et al., 1988). However, no differences in PFD frequency were detected between control and water stress treatments after storage. This disparity among fresh and stored fruit and the presence of pillowed fruit in nonstressed treatments suggested that the etiology of the defect is complex. Ambient temperatures during fruit enlargement in 1987 and 1988 were abnormally high (daily mean temperature for 1 to 15 Aug. 1987 and 1988 and the 20-year mean was 22.1, 26.2, and $20.4 \mathrm{C}$, respectively). High temperatures during fruit development may have caused an increase in PFD.

The symptomatology of PFD was progressive during storage. Postharvest changes can occur in fruit mesocarp tissue and PFD can increase during storage. In freshly harvested fruit, the porous texture and white discoloration characteristic of pillowed tissue were often difficult to detect, particularly in slightly pillowed fruits. When fruits were rated for PFD following storage, symptoms were pronounced. Increases in PFD severity of fruits stored at higher temperatures and VPD may be associated with increased rate of water loss and increased metabolic activity (respiration).

Negative correlations between fruit quality and PFD ratings suggested that the anomaly can affect processed product quality. For example, the characteristic tan to grayish-brown discoloration of pillowed tissue became increasingly objectionable (interior color ratings; data not presented) as the severity of PFD increased. The severity of PFD was also well correlated with softening of fruit. In a processed food product such as pickles, which is evaluated for quality by the consumer primarily on the basis of texture (Breene et al., 1972), softening associated with 
Table 3. Mean PFD ratings of fruits from cucumber plants subjected to water stress and several postharvest storage environments., ${ }^{z}$,

\begin{tabular}{|c|c|c|c|c|c|c|c|}
\hline \multirow[b]{3}{*}{ Variable } & \multicolumn{7}{|c|}{ Ratings for PFD } \\
\hline & \multicolumn{3}{|c|}{1987 Expt. } & \multicolumn{4}{|c|}{1988 Expt. } \\
\hline & 1 & 2 & 3 & 1 & 2 & 3 & 4 \\
\hline \multicolumn{8}{|l|}{ Siress treatment } \\
\hline Watered daily & $3.13 \mathrm{a}^{\mathrm{x}}$ & $3.08 \mathrm{~b}$ & $3.67 \mathrm{a}$ & $2.71 \mathrm{~b}$ & $2.61 \mathrm{~b}$ & $2.79 \mathrm{a}$ & $2.77 \mathrm{~b}$ \\
\hline Water withheld & $3.07 \mathrm{a}$ & $3.72 \mathrm{a}$ & $3.77 \mathrm{a}$ & $3.07 \mathrm{a}$ & $3.08 \mathrm{a}$ & $2.60 \mathrm{a}$ & $3.08 \mathrm{a}$ \\
\hline \multicolumn{8}{|c|}{ Environment (no.) ${ }^{\mathrm{w}}$} \\
\hline Unprocessed (fresh) & $1.95 \mathrm{~d}$ & $2.70 \mathrm{~b}$ & $3.25 \mathrm{~b}$ & $1.76 \mathrm{c}$ & $2.03 \mathrm{~b}$ & $2.06 \mathrm{~b}$ & $2.20 \mathrm{~b}$ \\
\hline 1 & $2.71 \mathrm{c}$ & $3.46 \mathrm{a}$ & $3.78 \mathrm{a}$ & $3.09 \mathrm{~b}$ & $2.37 \mathrm{~b}$ & $1.55 \mathrm{c}$ & $1.69 \mathrm{c}$ \\
\hline 2 & $3.30 \mathrm{~b}$ & $3.60 \mathrm{a}$ & $3.76 \mathrm{a}$ & $3.55 \mathrm{a}$ & $3.77 \mathrm{a}$ & $3.90 \mathrm{a}$ & $4.00 \mathrm{a}$ \\
\hline 3 & $3.97 \mathrm{a}$ & $3.66 \mathrm{a}$ & $3.81 \mathrm{a}$ & $3.68 \mathrm{a}$ & $3.55 \mathrm{a}$ & $3.68 \mathrm{a}$ & $4.00 \mathrm{a}$ \\
\hline
\end{tabular}

${ }^{2}$ Ratings for PFD, where $1=$ none, $2=$ slight $(1 \%$ to $20 \%), 3=$ moderate $(21 \%$ to $40 \%)$, and $4=$ severe $(>40 \%)$.

'Water stress treatments where control equals sufficient soil moisture for growth and development, and stress equals soil moisture withheld to cause wilting during second harvest fruit enlargement at Hancock, Wis.

${ }^{x}$ Mean separation within continuous columns by Duncan's multiple range test, $P=$ 0.05 .

"Postharvest storage environments where evaluations of PFD were made using fresh ( $3 \mathrm{~h}$ after harvest) and stored fruits (1987: $1=10.5 \mathrm{C}, 85 \% \mathrm{RH}, 4$ days; $2=15.5 \mathrm{C}$, $85 \% \mathrm{RH}, 4$ days; $3=26.5 \mathrm{C}, 75 \% \mathrm{RH}, 2$ days; and 1988:1 = 15.5C, 85\% RH, 4 days; $2=26.5 \mathrm{C}, 60 \% \mathrm{RH}, 2$ days; $3=26.5 \mathrm{C}, 75 \% \mathrm{RH}, 2$ days).

Table 4. Mean cucumber OVR and PFD ratings of processed fruit following water stress and several postharvest storage in controlled environments.

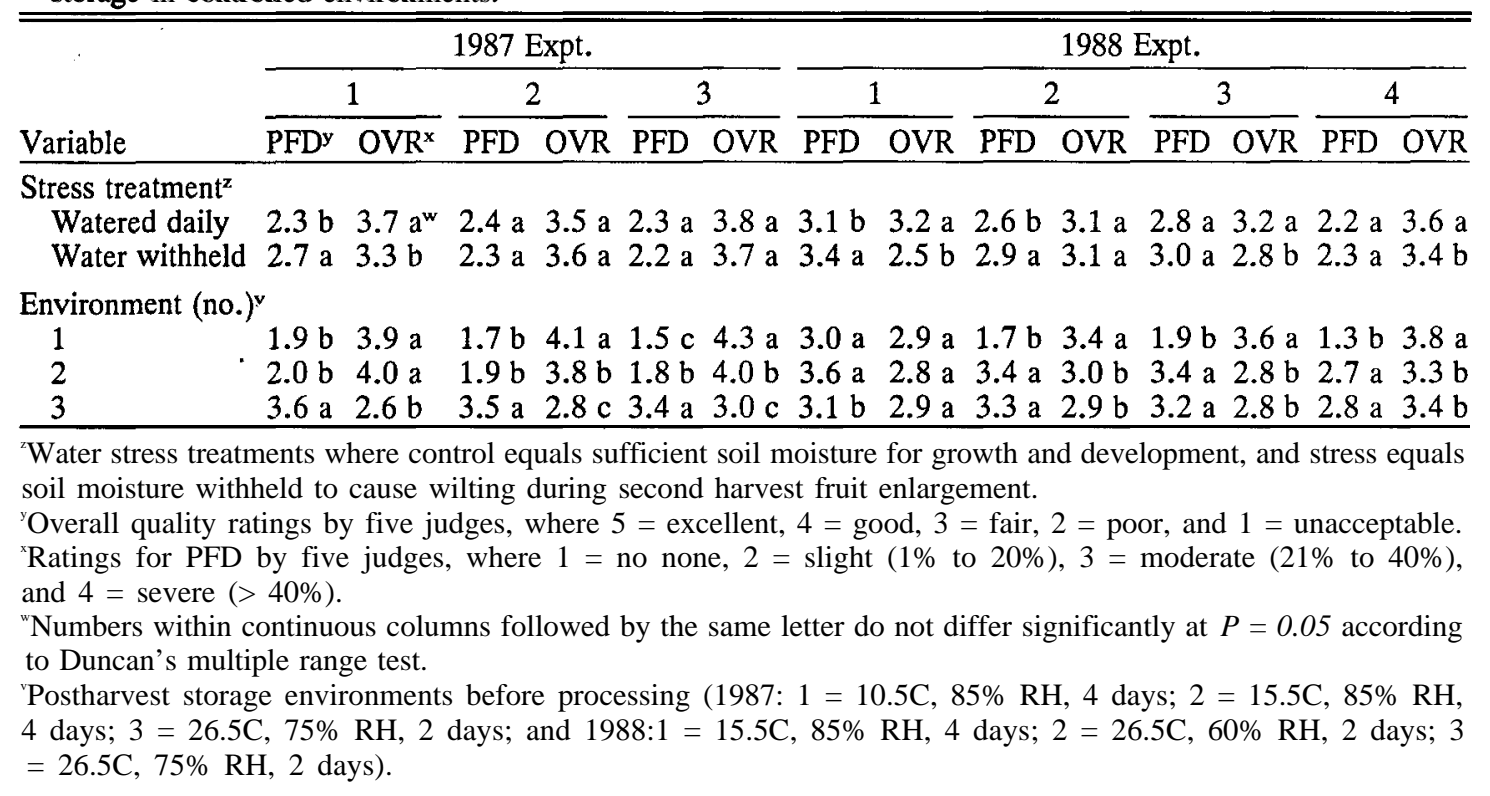

Table 5. Mean force required to compress mesocarp tissue of processed cucumber fruits.'

\begin{tabular}{lcc}
\hline \hline & \multicolumn{2}{c}{$\begin{array}{c}\text { Force }^{\mathrm{y}} \\
\left(\mathrm{kg} \cdot \mathrm{cm}^{-2}\right)\end{array}$} \\
\cline { 2 - 3 } $\begin{array}{l}\mathrm{F} \mathrm{r} \mathrm{u} \text { i } \mathrm{t} \\
\text { classification }\end{array}$ & $4.33 \pm 0.18$ & 1988 \\
\hline Nonpillowed & $2.90 \pm 0.14$ & $1.78 \pm 0.07$ \\
Pillowed & 0.01 & $1.08 \pm 0.04$ \\
$t$ Test, $P$ value & 0.01 \\
\hline${ }^{7}$ Means \pm sE; $\mathrm{N}=24$ fruit in $1987, \mathrm{~N}=17$ fruit in 1988. \\
${ }^{\mathrm{y}} 1987$ samples: $1.27 \mathrm{~cm}$ diameter $\times 0.48 \mathrm{~cm}$ thick; 1988 samples: \\
$1.75 \mathrm{~cm}$ diameter $\times 0.64$ cm thick; samples compressed to $75 \%$ of \\
original thickness.
\end{tabular}

PFD may have a negative impact on product acceptability in the marketplace. Although the nature of the postharvest physiological changes remains to be determined, appropriate postharvest management is critical for reducing the frequency and severity of PFD in pickled cucumber.

Despite similar Ca concentrations in leaf tissue samples of all treatments, mean mesocarp tissue Ca content of freshly sampled control fruits was higher (18\% to $56 \%)$ than that of fruits produced in stress plots. Staub et al. (1988) found an association between PFD and low tissue Ca levels. This observation led us to speculate that the observed anatomical anomalies in pillowed tissue were the result of localized deficiencies of Ca. Our present study provides support for this association. 
Fruit Ca status appears to be influenced by soil moisture (Engelkes et al., 1990). Therefore, it is reasonable to hypothesize that differences in fruit $\mathrm{Ca}$ content observed in the present study were due, in part, to the effects of water stress on translocation of $\mathrm{Ca}$ to enlarging fruits. Calcium concentrations in the fruit were considerably lower than those reported by Engelkes et al. (1990). The relatively low Ca levels in the fruit from both wellwatered and stress plots may provide a partial explanation for the high incidence of PFD in fruits harvested from well-watered plants. However, the frequency of PFD in control fruits increased following storage, suggesting that differences in the $\mathrm{Ca}$, content of fruits at harvest may not be indicative of the progressive development of PFD that can occur during storage.

The characterization of mechanisms for the regulation of $\mathrm{Ca}$ uptake and its distribution has been difficult (Bangerth, 1979). Nevertheless, based on the data presented in this and other reports (Engelkes et al., 1990; Staub et al., 1988), we hypothesize that, under plant water stress, the efficiency of translocation and distribution of $\mathrm{Ca}$ to cucumber fruits in their early stages of growth ( 2 to 4 days after pollination) may affect the development of PFD.

Manipulation of the genetic components of $\mathrm{Ca}$ uptake and distribution may be effective in overcoming Ca-related deficiencies (Marschner, 1983). Cultivar differences in susceptibility to $\mathrm{Ca}$ deficiencies have been reported (Greenleaf and Adams, 1969) and have a genetic basis (Giordano et al., 1982). Studies have identified cucumber cultivars that differ in susceptibility to PFD (Staub et al., 1988) and cultivar differences exist in fruit $\mathrm{Ca}$ accumulation rates (Engelkes et al., 1990). If the efficiency of translocation affects pillowy development and if genetic variation for $\mathrm{Ca}$ uptake and distribution exists in processing cucumber, then selection of genotypes efficient in the early accumulation of $\mathrm{Ca}$ may help to prevent the development of PFD in cucumbers.

\section{Literature Cited}

Bangerth, F. 1979. Calcium-related physiological disorders of plants. Annu. Rev. Phytopathol. 17:97-122.

Breene, W. M., D. Davis, and H. Chou. 1972. Texture profile analysis of cucumbers. J. Food Sci. 37:113-117.

Cho, T., H. Eguchi, M. Kurada, A. Tanaka, M. Koutaki, A.L. Ng, and T. Matsui. 1985. Effect of soil water potential on transpiration rate in cucumber plants. Biotronics 14:1-6.

de Giordano, L. B., W.H. Gabelman, and G.C. Gerloff. 1982. Inheritance of differences in calcium utilization by tomatoes under lowcalcium stress. J. Amer. Soc. Hort. Sci. 107:664-669.
Drews, M. 1979. The influence of some growth factors on water balance of greenhouse cucumbers. Archiv fur Gartenbau. 27:399410.

Engelkes, C.A., I. Widders, and H. Price. 1990. Ontogenetic changes in calcium concentrations and content in pickling cucumber fruit as influenced by genotype and environment. J. Amer. Soc. Hort. Sci. 115:555-558.

Greenleaf, W.H. and F. Adams. 1969. Genetic control of blossomed rot disease in tomatoes through calcium metabolism. J. Amer. Soc. Hort. Sci. 94:248-250.

Idso, S.B. 1982. Non-water-stressed baselines: A key to measuring and interpreting plant water stress. Agr. Meteorol. 27:59-70.

Idso, S. B., R.D. Jackson, P.J. Pinter, Jr., R.J. Reginato, and J.L. Hatfield. 1981. Normalizing the stress degree day parameter for environmental variability. Agr. Meteorol. 24:45-55.

Johnson, R. and G. Battacharyya. 1985. Statistics, principles and methods. Wiley, New York.

Marschner, H. 1983. General introduction to the mineral nutrition of plants, p. 5-60. In: A. Lauchli and R.L. Bielski (eds.). Inorganic plant nutrition. Springer-Verlag, Berlin.

Nagoaka, M., K. Takahashi, and K. Arai. 1984. Effect of environmental factors on photosynthesis and transpiration of tomato and cucumber plants (English summary only). Vegetable and Ornamental Crops Res. Sta., A. Ano Mie, Japan, Bul. 12. p. 97-117.

Ortega, D.G. and D.W. Kretchman. 1982. Water stress effects on pickling cucumbers. J. Amer. Soc. Hort. Sci. 107:409-412.

O'Sullivan, J. 1980. Irrigation, spacing, and nitrogen effects on yield and quality of pickling cucumbers grown for mechanical harvest. Can. J. Plant Sci. 60:923-928.

Reynolds, C.W. and B.L. Rogers. 1949. Irrigation studies with certain fruit and vegetable crops in MD. Maryland Agr. Expt. Sta. Bul. 463.

Schulte, E. E., G.B. Peters, and P.R. Hudson. 1987. Wisconsin procedures for soil, plant analysis and feed, forage analysis. no. 6 . Univ. of Wisconsin, Madison.

Standard Oil Engineered Materials Co. 1987. Scheduler plant stress monitor owner's manual. Standard Oil Engineered Materials Co., Solon, Ohio.

Staub, J. E., P. Rousos, and B.E. Struckrneyer. 1988. Anatomical characterization and possible role of calcium in "pillowy", a fruit disorder in processing cucumber. J. Amer. Soc. Hort. Sci. 113:905909.

Steel, R. and J.H. Torrie. 1980. Principles and procedures of statistics. 2nd ed. McGraw-Hill, New York.

Tan, C. W., J.M. Fulton, and V.W. Nuttall. 1983. The influence of soil moisture stress and plant population on yield of pickling cucumbers. Scientia Hort. 21:217-224.

Tan, C. S., J.M. Fulton, and V.W. Nuttall. 1983. The influence of soil moisture stress and plant population on yield of pickling cucumbers. Scientia Hort. 21:217-224. 